Огляди літератури, оригінальні дослідження, погляд на проблему, випадок з практики, короткі повідомлення УДК 617.721.6-002-085.37

DOI 10.11603/1811-2471.2021.v.i2.12209

\title{
РОЛЬ СD МАРКЕРІВ У РОЗВИТКУ ЗАПАЛЕННЯ УВЕАЛЬНОГО ТРАКТУ
}

\section{๑Н. Б. Курильців, О. В. Зборовська, Л. М. Величко, О. В. Богданова \\ ДУ «Інститут очних хвороб і тканинної терапії імені В. П. Філатова НАМН України», Одеса}

РЕЗЮМЕ. В патогенезі увеїту великий інтерес представляє виявлення загальних та специфічних порушень системних показників Т-клітинного імунітету і фагоцитарної ланки імунітету. На поверхні всіх імунних клітин розташована величезна кількість білків - CD-маркерів. Визначення CD-маркерів $\epsilon$ корисним як для діагностики, так і для лікування ряду захворювань. Існує обмаль робіт, які 6 стосувались визначення ролі конкретних CD-маркерів при запаленні увеального тракту.

Мета - вивчити рівень експресії маркера активації нейтрофілів CD15 та маркера апоптозу CD95 у хворих із середнім увеїтом.

Матеріал і методи. В дослідженні брали участь 26 практично здорових осіб та 26 пацієнтів із середнім увеїтом, у 15 з яких досліджували рівень експресії маркера апоптозу лімфоцитів CD15 (I група) та у 11 - рівень експресії маркера активації нейтрофілів CD95 в периферичній крові.

Результати. Встановлений високий рівень експресії молекулярного маркера апоптозу CD95 у хворих із середнім увеїтом. Цей показник склав у відсотковому відношенні $(28,5 \pm 4,9) \%$, в абсолютному - $(534,2 \pm 59,5)$ кл/мкл, (n=15). Водночас у здорових осіб ці показники були відповідно $(18,9 \pm 3,1) \%$ та $(254,5 \pm 42,1)$ кл/мкл, $(n=26),(p<0,05$ за критерієм Манна - Уїтні). Також встановлений високий рівень експресії маркера CD15, а саме - $(28,7 \pm 5,8) \%$, тобто $(980,19 \pm 58,4)$ кл/мкл $(n=11)$. У здорових осіб, відповідно, $(14,2 \pm 3,1) \%$ і $(165,5 \pm 32,1)$ кл/мкл $(n=26),(p<0,05$ за критерієм Манна - Уїтні).

Висновки. Оцінка субпопуляційного складу лімфоцитів і функціональної активності нейтрофілів периферичної крові при увеїтах різної етіології $є$ актуальною і необхідною через потребу фундаментального вивчення патогенезу запалення, а також з метою пошуку ефективних способів лікування та імунокорекції при різних формах увеїтів. Отримані результати наших досліджень та попередні дані з джерел літератури наштовхують нас на гіпотезу, що апоптоз лімфоцитів може сприяти розрішенню увеїту, проте нейтрофіли можуть бути відповідальними за пошкодження тканин. І от лікування, що спрямоване на імунокорекцію, а саме на пригнічення впливу нейтрофілів, може мати терапевтичну цінність. Але ці припущення, безумовно, потребують подальшого вивчення.

КлючовІ СлОВА: середній увеїт; CD15; CD95; апоптоз; лімфоцити; нейтрофіли.

Вступ. Численні дослідження останніх років демонструють вагому роль імунних реакцій у розвитку запалення увеального тракту. Патогенез увеїту пов'язаний не тільки з локальними імунними реакціями, а й із системними імунними порушеннями [1]. Найбільший інтерес становить виявлення загальних та специфічних порушень системних показників Т-клітинного імунітету і фагоцитарної ланки імунітету, які супроводжують і, можливо, $\epsilon$ причинами різних форм увеїтів [2-4].

Імунна привілея ока обмежує діапазон імунних механізмів, які призводять до інтенсивного деструктивного запалення, забезпечуючи захист очей від патогенних мікроорганізмів. Для підтримки цієї привілеї в оці є анатомічний субстрат гематоофтальмічний бар'єр, лімфатична система зі своїми особливостями, а також молекулярні механізми, що забезпечують секрецію різних імуносупресивних факторів [5]. Механізми імунної привілеї ока індукують апоптоз, сприяють виробленню протизапальних цитокінів та опосередковують активацію антиген-специфічного регуляторного імунітету. Ці механізми також намагаються вплинути на імунні процеси всередині ока, в якому розвивається запалення судинного тракту [6]. Периферична толерантність підтримується антиген-специфічними Т-регуляторними клітинами, які запобігають автоімунним захворюванням, підтримуючи автотолерантність та запобігаючи зсувам імунітету [7]. Увеїт же виникає, якщо цей імунний баланс порушується під впливом ендогенних або екзогенних факторів. Це призводить до міграції нейтрофілів та макрофагів до вогнища запалення. Активовані клітини виробляють цитокіни, що беруть участь у формуванні системної та місцевої імунної відповіді. Дія медіаторів запалення призводить до структурно-функціональної дезорганізації сполучної тканини, порушення мікроциркуляції, що зумовлює появу гіпоксії, ішемії та безлічі інших патологічних змін у тканинах ока. Неінфекційний увеїт виникає в результаті неадекватної активації імунної системи, тому не завжди зрозумілим $є$ його зв'язок із системними автоімунними захворюваннями. Якщо цей зв'язок не ідентифікований, увеїт вважається ідіопатичним.

Крім того, на поверхні всіх імунокомпетентних клітин розташована величезна кількість білків. Ці білки можна виявити за допомогою моноклональних антитіл. Моноклональні антитіла - це антитіла однієї специфічності, отримані від нащадків клітини, сенсибілізованої до певного антигену. Вивчення поверхневих білків дає змогу ідентифікувати 
Огляди літератури, оригінальні дослідження, погляд на проблему, випадок з практики, короткі повідомлення клітини (що особливо важливо стосовно лімфоцитів із подібною морфологією), оцінити ступінь їхньої зрілості, їхній функціональний стан. Для уніфікації опису поверхневих білків клітин було прийнято абревіатуру «CD». CD - з англійської «сluster of differentiation, cluster designation» - кластер диференціювання. У 1982 році робоча група HLDA (Human Leukocyte Differentiation Antigens) запропонувала визначення та класифікацію CD-антигенів або CD-маркерів, якими можуть бути білки, що служать рецепторами або лігандами, які беруть участь у взаємодії клітин між собою і $\epsilon$ компонентами каскаду визначених сигнальних шляхів. Початковою ідеєю цієї робочої групи було класифікувати різні моноклональні антитіла проти клітинних поверхневих молекул лейкоцитів, які були створені різними лабораторіями у всьому світі. Кількість CD-маркерів, які вивчались, постійно зростала і збільшувалася по відношенню до інших типів клітин. Сьогодні існує понад 350 відомих кластерів CD і їх підтипів, описаних у людей. Частина з них добре вивчена майже у всіх галузях медицини, але частина потребує більш детального розуміння та вивчення при багатьох захворюваннях, в тому числі при увеїтах $[8,9]$.

У літературних джерелах описані результати небагатьох досліджень ролі CD-маркерів при увеїтах. У 2018 році у США була проведена експериментальна робота на мишах, у ході якої вивчали вплив CD6 у розвитку автоімунного увеїту та впливу на терапію даного захворювання [10]. Ще одне дослідження стосувалось вивчення ролі макрофагів у розвитку автоімунного запалення в оці експериментальних тварин, які несуть на своїй поверхні ряд CD-маркерів [7].

Отже, вивчення імуноопосередкованих запальних реакцій увеального тракту та клітин, які беруть безпосередню участь у цьому, $\epsilon$ надзвичайно актуальною проблемою та потребує подальшого детального дослідження. Більше того, визначення CD-маркерів $\epsilon$ корисним як для діагностики, так і для лікування ряду захворювань. Наявність того чи іншого маркера на поверхні тієї чи іншої клітини може свідчити про розвиток різних конкретних патологічних процесів в організмі загалом та безпосередньо в очному яблуці.

Мета - вивчити рівень експресії маркера активації нейтрофілів CD15 та маркера апоптозу CD95 у хворих із середнім увеїтом.

Матеріал і методи дослідження. В дослідженні брали участь 52 особи, 26 з яких практично здорові (контрольна група) та 26 - пацієнти 3 середнім увеїтом. I група включала 15 пацієнтів, у яких досліджували рівень експресії маркера апоптозу лімфоцитів CD15. II група складалась 3 11 пацієнтів з тією ж патологією, в яких досліджували рівень експресії маркера активації нейтрофілів CD95. Вивчення рівня експресії маркерів CD15 та CD95 проводили з периферичної крові досліджуваних імуногістохімічним методом. Вік паці$\epsilon$ нтів I та II груп складав (34 \pm 11$)$ років, а здорових осіб контрольної групи - $(36 \pm 10)$ років відповідно.

Результати й обговорення. Накопичення лімфоцитів у місці запалення контролюється їхнім рівнем та міграцією з місця запалення, а також їхнім темпом поширення й апоптозу. Доведено, що апоптоз лімфоцитів відіграє ключову роль у підтриманні імунних процесів в оці та пригнічує запалення [11]. Апоптоз - форма регульованої загибелі клітин, при якій під впливом певних стимулів у клітині-мішені відбувається ушкодження ядерного матеріалу (хроматину), що супроводжується його фрагментацією. Процес загибелі завершується поглинанням клітини макрофагом. На відміну від лізису, для апоптозу не характерні руйнування мембрани клітини, вивільнення її вмісту і запуск запальних реакцій. В імунній системі в нормі апоптоз «вирішує» такі завдання: 1) елімінація попередників лімфоцитів, здатних розпізнавати власні тканини, тобто які несуть ознаки автореактивності; 2) елімінація нефункціонуючих клонів циркулюючих лімфоцитів; 3) елімінація активних лімфоцитів після припинення антигенної стимуляції з метою завершення імунної відповіді. Апоптоз лімфоцитів може індукуватися двома шляхами: взаємодією CD95 та його рецепторів, а також через вплив факторів росту. Перший шлях регулює рівень зростання імунної відповіді, а от апоптоз другого типу призводить до розрішення запалення $[12,13]$. Також існують дані про додаткові шляхи апоптозу, що включає виведення цитокінів та перфорин-залежний лізис клітин-мішеней [14].

Оскільки маркер кластерної диференціації CD95 безпосередньо бере участь у апоптозі, він може слугувати показником даного процесу. Цей маркер визначається в периферичній крові паці$\epsilon$ нтів, але факт наявності його в середовищах та тканинах ока при увеїтах ще не до кінця вивчений. Відомо, що CD95 відіграє ключову роль у підтриманні очної привілеї. У конкретних умовах, залежно від імунологічного середовища, CD95 має протизапальні властивості й може взаємодіяти з лімфоцитами Th17 та нейтрофілами, тобто двома клітинами, причетними до неінфекційного увеїту. Гіпотетично, рівні CD95 можуть бути прогностичним фактором при неінфекційному увеїті та вивчення задіяних молекулярних механізмів може забезпечити нові терапевтичні цілі.

Однак у літературі існують суперечливі погляди стосовно впливу CD95 та виду апоптозу на розвиток і завершення автоімунного запалення. В роботах ряду авторів описано результати експе- 
Огляди літератури, оригінальні дослідження, погляд на проблему, випадок з практики, короткі повідомлення риментальних досліджень, у процесі яких вивчали не тільки автоімунний увеїт, а й алергічний енцефаломієліт, автоімунний тиреоїдит, цукровий діабет і артрит. Автори вказують на те, що нормальна експресія CD95 на поверхні клітин імунної системи $є$ важливою для інтенсивного розвитку автоімунних процесів. Водночас відсутність його на тій же поверхні клітин у досліджуваних середовищах експериментальних тварин не впливає на виражені прояви автоімунного запалення [15-18]. Усі ці факти підкреслюють необхідність подальшого детального вивчення вказаних механізмів імунних реакцій. Це, можливо, дасть змогу зрозуміти роль того чи іншого маркера в автоімунному компоненті внутрішньоочного запалення.

Нами проведене дослідження показника рівня маркера апоптозу CD95 периферичної крові 11 пацієнтів із середнім увеїтом. У хворих даної групи встановлений високий рівень експресії молекулярного маркера CD95 на лімфоцитах. Цей показник перевищив нормативні значення і склав у відсотковому співвідношенні $(28,5 \pm 4,9) \%$, а в а6солютному - $(534,2 \pm 59,5)$ кл/мкл $(n=11)$. Водночас у здорових осіб ці показники були, відповідно, $(18,9 \pm 3,1) \%$ та $(254,5 \pm 42,1)$ кл/мкл $(n=26)$, що відповідало р<0,05 за критерієм Манна - Уїтні.

Крім того, в імунних реакціях організму при захворюваннях увеального тракту важливу роль відіграють нейтрофіли. Ці клітини крові добре відомі своїми фагоцитарними властивостями, вони характеризуються найкоротшим напіврозпадом серед лейкоцитів. У процесі своєї «роботи» в імунних реакціях нейтрофіли можуть неконтрольовано виділяти цитотоксичні молекули, накопичення яких призводить до запалення та руйнування тканин. У такому випадку апоптоз рятує клітин і тканини від загибелі [19]. Оцінка кожної стадії фагоцитозу важлива для ідентифікації «поломок», які виникають у результаті вродженого чи набутого дефектів фагоцитарної активності. Тому доцільно вивчати всі стадії фагоцитозу і різницю рівнів молекулярних маркерів цього процесу.

Серед молекулярних маркерів активації нейтрофілів привертає увагу саме CD15, за рівнем якого можна визначити фагоцитарну активність нейтрофілів при розвитку запалення судинної оболонки ока. Саме тому в проведеному нами дослідженні ми вивчали рівень експресії маркера CD15 на нейтрофілах, щоб зрозуміти реакцію їх на запальний процес в увеальному тракті. У всіх хворих із середнім увеїтом виявлено високий рівень експресії даного маркера. Значення його складали у відсотковому відношенні $(28,7 \pm 5,8) \%$, в абсолютному - $(980,19 \pm 58,4)$ кл/мкл $(n=11)$. У здорових осіб ці показники були нижчі й складали, відповідно, $(14,2 \pm 3,1) \%$ і $(165,5 \pm 32,1)$ кл/мкл $(n=26),(p<0,05$ за критерієм Манна - Уїтні).

Виходячи з вищеописаного можна стверджувати, що робота імунної системи та імунна відповідь відіграють ключову роль у розвитку внутрішньоочного запалення, тобто імунні порушення займають важливе місце в етіопатогенезі увеїтів. Імунні зсуви можуть як ініціювати даний стан, або ж посилювати тяжкість запального процесу, так і супроводжувати запальний автоімунний процес, не особливо впливаючи на його перебіг.

Висновки. Таким чином, отримані результати наших досліджень та попередні дані з джерел літератури наштовхують нас на гіпотезу, що апоптоз лімфоцитів може сприяти розрішенню увеїту, проте нейтрофіли можуть бути відповідальними за пошкодження тканин. І от лікування, що спрямоване на пригнічення впливу нейтрофілів, може мати терапевтичну цінність, як при контрольованому Т-лімфоцитами процесі, так і при нейтрофільно-опосередкованому запаленні. Але ці припущення, безумовно, потребують подальшого вивчення.

Більше того, оцінка субпопуляційного складу лімфоцитів і функціональної активності нейтрофілів периферичної крові при увеїтах різної етіології $\epsilon$ актуальною і необхідною не тільки через потребу фундаментального вивчення патогенезу запального процесу, а й з метою пошуку ефективних способів лікування. Окрім застосування стандартних методів лікування, що спрямовані на боротьбу з запаленням, детоксикацію, десенсибілізацію, доцільно вводити у комплексну терапію лікувальні засоби для імунокорекції. Цей крок дасть можливість запобігти імуноопосередкованому ураженню тканин ока, що, в свою чергу, дозволить уникнути зниження гостроти зору та інвалідизації пацієнта.

Перспективи подальших досліджень. Вважаємо за необхідне вивчення інших важливих молекулярних маркерів запалення судин ока, що дасть можливість зрозуміти їх вплив на перебіг запалення, більше того, зрозуміти їхню взаємодію між собою та спільну дію на імунні реакції організму в цілому та ока як окремого органа. Необхідність цього пошуку підтверджує також факт порушення гематоофтальмічного бар'єру при увеїтах, що призводить до появи тих же імунокомпетентних клітин у середовищах ока. 


\section{ЛІТЕРАТУРА}

1. Goldstein D. A. Classification, symptoms, and signs of uveitis. Duane's Ophthalmology / D. A. Goldstein, D. Pyatetsky, H. H. Tessler; in Tasman W., Jaeger E. A., eds. - 15th edn. Ch. 32. - Philadelphia, Pa: Lippincott Williams \& Wilkins, 2009.

2. Caspi R. R. A look at autoimmunity and inflammation in the eye / R. R. Caspi // J. Clin. Invest. - 2010. Vol. 120 (9). - P. 3073-3083.

3. Interplay between innate and adaptive immunity in the development of noninfectious uveitis / F. Willermain, J. T. Rosenbaum, B. Bodaghi [et al.] // Prog. Retin. Eye Res. - 2012. - Vol. 31 (2). - P. 182-194.

4. Калюжин О.В.Иммунные механизмы экспериментальных увеоретинитов / О. В. Калюжин, 3. Х. Дикинов, И. В. Евсегнеева // Курский научно-практический вестник «Человек и его здоровье». - 2011. - № 1. - С. 153-159.

5. Immunotherapeutic strategies in autoimmune uveitis / P. H. Papotto, E. B. Marengo, L. R. Sardinha [et al.] // Autoimmun. Rev. - 2014. - Vol. 13. - P. 909-916.

6. Taylor A. W. Ocular immune privilege / A. W. Taylor // Eye (Lond). - 2009. - Vol. 23. - P. 1885-1889.

7. Macrophages and uveitis in experimental animal models / S. Mérida, E. Palacios, A. Navea, F. Bosch-Morell // Mediators Inflamm. - 2015. - Vol. 2015. - P. 671417.

8. CD molecules 2006--human cell differentiation molecules / H. Zola, B. Swart, A. Banham [et al.] // J. Immunol. - 2007. - Vol. 319 (1-2). - P. 1-5.

9. CD Nomenclature 2015: Human Leukocyte Differentiation Antigen Workshops as a Driving Force in Immunology / P. Engel, L. Boumsell, R. Balderas [et al.] // J. Immunol. - 2015. - Vol. 195 (10). - P. 4555-4563.

10. Targeting CD6 for the treatment of experimental autoimmune uveitis / L. Zhang, Y. Li, W. Qiu [et al.] // J. Autoimmunity. - 2018. - Vol. 90. - P. 84-93.

11. Apoptosis of infiltrating cells in experimental autoimmune uveoretinitis / P. Yang, N. H. Herzberg, H. Zhou [et. al.] // Chin. Med. J. (Engl). - 2000. - Vol. 113 (7). - P. 643-646.

12. An IL-2-dependent switch between CD95 signaling pathways sensitizes primary human $T$ cells toward CD95-mediated activation-induced cell death / I. Schmitz, A. Krueger, S. Baumann [et al.] // J. Immunol. - 2003. Vol. 171 (6). - P. 2930-2936.

13. Marrack. P. Control of T cell viability / P. Marrack, J. Kappler // Annu. Rev. Immunol. - 2004. - Vol. 22. P. 765-787.

14. Expression and regulation of fas and fas ligand on thyrocytes and infiltrating cells during induction and resolution of granulomatous experimental autoimmune thyroiditis / Y. Wei, K. Chen, G. C. Sharp [et al.] // J. Immunol. 2001. - Vol. 167 (11). - P. 6678-6686.

15. A targeted DNA vaccine encodingfasligand defines its dual role in the regulation of experimentalautoimmune encephalomyelitis / G. Wildbaum, J. Westermann, G. Maor, N. Karin // J. Clin. Invest. - 2000. - Vol. 106 (5). P. 671-679.

16. Significant role for Fas in the pathogenesis of autoimmune diabetes / X. Su, Q. Hu, J. M. Kristan [et al.] // J. Immunol. - 2000. - Vol. 164 (5). - P. 2523-2532.

17. Fas-mediated apoptosis in clinical remissions of relapsing experimental autoim-mune encephalomyelitis / G. C. Suvannavejh, M. C. Dal Canto, L. A. Matis, S. D. Miller / J. Clin. Invest. - 2000. - Vol. 105 (2). - P. 223-231.

18. Fas and Fas ligand expressed on cells of the immune system, not on the target tissue, control induction of experimental autoimmune uveitis / J. L. Wahlsten, H. L. Gitchell, C. C. Chan [et al.] // J. Immunol. - 2000. - Vol. 165 (10). P. 5480-5486.

19. Immunology and infection development and identification of a novel subpopulation of human neutrophilderived giant phagocytes in vitro / L. Lavie, L. Dyugovskaya, A. Polyakov [et al.] // J. Vis. Exp. - 2017. - Vol. 119. P. 54826.

\section{REFERENCES}

1. Goldstein, D.A., Pyatetsky, D., \& Tessler, H.H. (2009). Classification, symptoms, and signs of uveitis. Duane's Ophthalmology. Tasman W., Jaeger E. A. (Eds.). 15th edn. Ch. 32. Philadelphia, Pa: Lippincott Williams \& Wilkins.

2. Caspi, R.R. (2010). A look at autoimmunity and inflammation in the eye. J. Clin. Invest., 120 (9), 3073-3083. DOI: $10.1172 / \mathrm{JCl} 42440$

3. Willermain, F., Rosenbaum, J.T., Bodaghi, B., Rosenzweig, H.L., Childers, S., Behrend, T., \& Dick, A.D. (2012). Interplay between innate and adaptive immunity in the development of noninfectious uveitis. Prog. Retin. Eye Res., 31 (2), 182-194. DOI: 0.1016/j.preteyeres.2011.11.004

4. Kalyuzhin, O.V., Dikinov, Z.Kh., \& Yevsegneyeva, I.V. (2011). Immunnyye mekhanizmy eksperimentalnykh uveoretinitov [Immune mechanisms of experimental uveoretinitis]. Kurskiy nauchno-prakticheskiy vestnik "Chelovek $i$ yego zdorovye» - Kursk Scientific and Practical Bulletin "Man and his Health", 1, 153-159 [in Russian].

5. Papotto, P.H., Marengo, E.B., Sardinha, L.R., Goldberg, A.C., \& Rizzo, L.V. (2014). Immunotherapeutic strategies in autoimmune uveitis. Autoimmun. Rev., 13, 909-916. DOI: 10.1016/j.autrev.2014.05.003

6. Taylor, A.W. (2009). Ocular immune Privilege. Eye., 23, 1885-1889. DOI: 10.1038/eye.2008.382.

7. Merida, S., Palacios, E., Navea, A., \& Bosch Morell, F. (2015). Macrophages and uveitis in experimental animal models. Mediators Inflamm., 2015, 671417. DOI: $10.1155 / 2015 / 671417$

8. Zola, H., Swart, B., Banham, A., Barry, S., Beare, A. Bensussan, A., \& Clark, G. (2007). CD molecules 2006--human cell differentiation molecules. J. Immunol., 319 (1-2), 1-5. DOI: 10.1016/j.jim.2006.11.001

9. Engel, P., Boumsell, L., Balderas, R., Bensussan, A., Gattei, V., Horejsi, V., \& Clark, G. (2015). CD Nomenclature 2015: human leukocyte differentiation antigen workshops as a driving force in immunology. J. Immunol., 195 (10), 
Огляди літератури, оригінальні дослідження, погляд на проблему, випадок з практики, короткі повідомлення

\section{5-4563. DOI: 0.4049/jimmunol.1502033}

10. Zhang, L., Li, Y., Qiu, W., Bell, B.A., Dvorina, N., Baldwin, W.M., \& Lin, F. (2018). Targeting CD6 for the treatment of experimental autoimmune uveitis. J. Autoimm., 90, 84-93. DOI: 10.1016/j.jaut.2018.02.004

11. Yang, P., Herzberg, N.H., Zhou, H., Broersma, L., de Smet, M., \& Kijlstra, A. (2000). Apoptosis of infiltrating cells in experimental autoimmune uveoretinitis. Chin. Med. J. (Engl)., 113 (7), 643-646.

12. Schmitz, I., Krueger, A., Baumann, S., SchulzeBergkamen, H., Krammer, P.H., \& Kirchhoff, S. (2003). An IL-2-dependent switch between CD95 signaling pathways sensitizes primary human T cells toward CD95-mediated activation-induced cell death. J. Immunol., 171 (6), 2930-2936. DOI: 10.4049/jimmunol.171.6.2930

13. Marrack, P. (2004). Control of T cell viability. Annu. Rev. Immunol., 22, 765-787. DOI: 10.1146/annurev.immunol.22.012703.104554

14. Wei, Y., Chen, K., Sharp, G.C., Yagita, H., \& BraleyMullen, H. (2001). Expression and regulation of fas and fas ligand on thyrocytes and infiltrating cells during induction and resolution of granulomatous experimental autoimmune thyroiditis J. Immunol., 167 (11), 6678-6686. DOI: $10.4049 /$ jimmunol.167.11.6678
15. Wildbaum, G., Westermann, J., Maor, G., \& Karin, N. (2000). A targeted DNA vaccine encodingfasligand defines its dual role in the regulation of experimentalautoimmune encephalomyelitis. J. Clin. Invest., 106 (5), 671-679. DOI: $10.1172 / \mathrm{JCl} 8759$

16. Su, X., Hu, Q., Kristan, J.M., Costa, C., Shen, Y., Gero, D., \& Wang, Y. (2000). Significant role for Fas in the pathogenesis of autoimmune diabetes. J. Immunol., 164 (5), 2523 2532. DOI: 10.4049 /jimmunol.164.5.2523

17. Suvannavejh, G.C., Dal Canto, M.C., Matis, L.A., \& Miller, S.D. (2000). Fas-mediated apoptosis in clinical remissions of relapsing experimental autoim-mune encephalomyelitis. J. Clin. Invest., 105 (2), 223-231. DOI: 10.1172/ $\mathrm{JCl} 8561$

18. Wahlsten, J.L., Gitchell, H.L., Chan, C.C., Wiggert, B., \& Caspi, R.R. (2000). Fas and Fas ligand expressed on cells of the immune system, not on the target tissue, control induction of experimental autoimmune uveitis. Immunol., 165 (10), 5480-5486. DOI: 10.4049/jimmunol.165.10.5480

19. Lavie, L., Dyugovskaya, L., Polyakov, A., Rogovoy, O., \& Leder, E. (2017). Immunology and infection development and identification of a novel subpopulation of human neutrophil-derived giant phagocytes in vitro. J. Vis. Exp., 119, 54826. DOI: 10.3791/54826

\title{
РОЛЬ СD МАРКЕРОВ В РАЗВИТИИ ВОСПАЛЕНИЯ УВЕАЛЬНОГО ТРАКТА
}

\author{
○Н. Б. Курыльцив, А. В. Зборовская, Л. Н. Величко, А. В. Богданова
}

ГУ «Институт глазных болезней и тканевой терапии имени В. П. Филатова НАМН Украины», Одесса

PЕЗЮМЕ. В патогенезе увеита большой интерес представляет выявление общих и специфических нарушений системных показателей Т-клеточного иммунитета и фагоцитарного звена иммунитета. На поверхности всех иммунных клеток есть огромное количество белков - CD-маркеров. Определение CD-маркеров является полезным как для диагностики, так и для лечения ряда заболеваний. В источниках литературы существует мало работ, касающихся определения роли конкретных CD-маркеров при воспалении увеального тракта.

Цель - изучить уровень экспрессии маркера активации нейтрофилов CD15 и маркера апоптоза CD95 у $60 л ь-$ ных со средним увеитом.

Материал и методы. В исследовании принимали участие 26 практически здоровых лиц и 26 пациентов со средним увеитом, у 15 из которых исследовали уровень экспрессии маркера апоптоза лимфоцитов CD15 (I группа) и у 11 - уровень экспрессии маркера активации нейтрофилов CD95 в периферической крови.

Результаты. Установлен высокий уровень экспрессии молекулярного маркера апоптоза CD95 у больных со средним увеитом. Этот показатель составил в процентном отношении - $(28,5 \pm 4,9)$ \%, в абсолютном - $(534,2 \pm$ $59,5)$ кл/мкл $(n=15)$. В то же время у здоровых лиц эти показатели были, соответственно, $(18,9 \pm 3,1) \%$ и $(254,5 \pm$ $42,1)$ кл/мкл ( $\mathrm{n}=26),(\mathrm{p}<0,05$ по критерию Манна - Уитни). Также установлен высокий уровень экспрессии маркера CD15, а именно - $(28,7 \pm 5,8) \%$, то есть $(980,19 \pm 58,4)$ кл/мкл (n=11). У здоровых лиц, соответственно, $(14,2 \pm 3,1) \%$ и $(165,5 \pm 32,1)$ кл/мкл (n=26) (р<0,05 по критерию Манна -Уитни).

Выводы. Оценка субпопуляционного состава лимфоцитов и функциональной активности нейтрофилов периферической крови при увеитах различной этиологии является актуальной и необходимой из-за необходимости фундаментального изучения патогенеза воспаления, а также с целью поиска эффективных способов лечения и иммунокоррекции при различных формах увеитов. Полученные результаты наших исследований и предварительные данные из источников литературы наталкивают нас на гипотезу, что апоптоз лимфоцитов может способствовать разрешению увеита, однако нейтрофилы могут быть ответственными за повреждение тканей. $И$ лечение, направленное на иммунокоррекцию, а именно на подавление влияния нейтрофилов, может иметь терапевтическую ценность. Но эти предположения, безусловно, требуют дальнейшего изучения.

КЛЮЧЕВЫЕ СЛОВА: средний Увеит; CD15; CD95; апоптоз; лимфоциты; нейтрофилы. 
Огляди літератури, оригінальні дослідження, погляд на проблему, випадок з практики, короткі повідомлення ROLE OF CD MARKERS IN THE DEVELOPMENT OF UVEAL INFLAMMATION

\section{@N. B. Kuryltsiv, O. V. Zborovska, L. M. Velichko, A. V. Bogdanova}

SI "V. Filatov Institute of Eye Diseases and Tissue Therapy of the National Academy of Medical Sciences of Ukraine", Odesa, Ukraine

SUMMARY. It is great interest to identify general and specific disorders of systemic of T-cell immunity and phagocytic immunity in the pathogenesis of uveitis. On the surface of all immune cells there is a huge amount of proteins - CD markers. Determination of CD markers is useful for both diagnosis and treatment of different diseases. There is poor information about specific CD markers in inflammation of the uveal tract in the literature.

The aim - to evaluate the expression level of the neutrophil activation marker CD15 and the apoptosis marker CD95 in patients with intermediate uveitis.

Material and Methods. The study involved 26 apparently healthy individuals and 26 patients with intermediate uveitis, in 15 of which the level of expression of the marker of apoptosis of lymphocytes CD15 (group I) and in 11 - the level of expression of the marker of activation of neutrophils CD95 in the peripheral blood were studied.

Results. A high level of expression of the molecular marker of apoptosis CD95 was found in patients with intermediate uveitis. This indicator was $-28.5 \pm 4.9 \%$ that was $534.2 \pm 59.5$ cells $/ \mu l,(n=15)$. At the same time, in healthy individuals these parameters were $18.9 \pm 3.1 \%$ and $254.5 \pm 42.1$ cells/ $\mu \mathrm{L}$, respectively, $(n=26),(p<0.05$ according to the Mann-Whitney test). Also, a high level of expression of the CD15 marker was established, namely, $28.7 \pm 5.8 \%$, that was $980.19 \pm$ 58.4 cells $/ \mu \mathrm{L}(\mathrm{n}=11)$. At the same time, in healthy individuals these parameters were $14.2 \pm 3.1 \%$ and $165.5 \pm 32.1 \mathrm{cells} / \mu \mathrm{L}$, ( $n=26)$, ( $p<0.05$ according to the Mann-Whitney test).

Conclusions. In summary, the assessment of the subpopulations of lymphocytes and the functional activity of peripheral blood neutrophils in uveitis of various etiologies is extremely necessary because of the necessity of fundamental study of the pathogenesis of inflammation, and also of finding effective methods of treatment and immune correction of this pathology. Our findings and previous literature data lead us to the hypothesis that apoptosis of lymphocytes may lead to the resolution of uveitis, but neutrophils may be responsible for tissue damage. And immune correction, as suppression of the effect of neutrophils, may have therapeutic value. But these assumptions certainly warrant further study.

KEY WORDS: intermidiate uveitis; CD15; CD95; apoptosis; lymphocytes; neutrophils.

Отримано 23.03.21 